\title{
The Effect of Cash Holding, Profitability, and Financial Leverage on Firm Value with Earnings Management as Moderating Variables in Manufacturing Companies Listed on the Indonesia Stock Exchange
}

\author{
Doddy Irawan \\ Master of Management, Sriwijaya University, Palembang, Indonesia \\ Corresponding author email: doddy_kaes@yahoo.com \\ Marlina Widiyanti \\ Lecturer of Master Management, Economic Faculty, Sriwijaya University, Palembang, Indonesia \\ Email: marlinawidiyanti68@yahoo.co.id

\section{Luk Luk Fuadah} \\ Lecturer of Master Management, Economic Faculty, Sriwijaya University, Palembang, Indonesia \\ Email: lukluk.fuadah@gmail.com \\ Mohamad Adam \\ Lecturer of Master Management, Economic Faculty, Sriwijaya University, Palembang, Indonesia \\ Email:mr_adam88@unsri.ac.id
}

\begin{abstract}
This study aims to determine the effect of cash holding, profitability (ROA), financial leverage (DER) on firm value $(P B V)$ with earnings management as a moderating variable in manufacturing companies listed on the Indonesia Stock Exchange. The sample of this research is 24 companies in the manufacturing sector with a research period from 2015-2020. The data analysis technique used in this study is moderated regression analysis (MRA). The results showed that cash holding and earnings management did not affect firm value (PBV). Profitability, as measured by return on assets (ROA) and financial leverage as measured by debt to equity ratio (DER), has a significant positive effect on firm value $(P B V)$. The results also conclude that earnings management does not have a moderating role in the effect of cash holding, profitability (ROA), financial leverage (DER) on firm value (PBV).
\end{abstract}

Keywords---cash holding, earnings management, financial leverage (DER), firm value (PBV), profitability (ROA).

\section{Introduction}

Since its inception, the company generally has had short, medium, and long-term goals. The company's goal is to earn much profit, and good management is needed. In addition to efficient management in various sectors, utilizing the company's internal and external resources is also required. One of the external sectors is related to investors or investors who expect profits from investing in companies. The company's image or the value of the company is built, one of which is from investor sentiment in the market based on company returns and performance (Villalonga \& Amit, 2006; Cashman et al., 2012).

In terms of market capitalization, the manufacturing sector reached IDR 2,126.74 trillion or $30.5 \%$ of the total market capitalization on the Indonesia Stock Exchange (IDX), where this number is quite significant and almost a third of the capitalization on the Indonesia Stock Exchange (IDX). This sector is the primary industrial sector with the largest market capitalization after the Finance sector in 2020 and has a positive performance in 5 years. For this 
reason, this sector is one of the most attractive sectors for investors to invest in (Alsyouf, 2007; Pasiouras \& Kosmidou, 2007).

The company's management needs to manage investments properly and not ignore the risk factors that will arise from selecting these investments. Profit, cash, and debt management need to be done for the company's survival. Companies that are good at managing capital and efficient in managing it will make the company have a good assessment of the market (Shalahuddin et al., 2020).

Many previous studies that examined this matter saw how the influence of cash holding, profitability, financial leverage on firm value, and the role of earnings management moderated the relationship between variables (McNichols, 2000; Lo, 2008; Anton et al., 2020). Many studies have found different or varied results, so there is a research gap (Doan, 2020; Rocca \& Cambrea, 2019; HC et al., 2019), which found that cash holding had a positive effect on firm value. At the same time, the research of Do et al. (2016), concluded that cash holding does not have a significant effect on firm value.

Ratulangi (2021), Mubyarto (2020), Antoro et al. (2020), Tumanggor (2019), found that profitability had a significant positive effect on firm value. Research that found similar was the research of Dewi \& Suputra (2019), Fajaria \& Isnalita (2018), Bukit et al. (2018), Agrippina et al. (2017), Sucuahi \& Cambarihan, (2016). Different results are shown by the research of Lamtiar et al. (2021), Sulastri et al. (2018), which found no effect of profitability on firm value. Aryantika \& Sujana (2018), concluded different results.

Jihadi et al. (2021), Burhanuddin et al. (2019), found that financial leverage positively affected firm value. Meanwhile, research by Butar-Butar et al. (2021), did not find the effect of leverage on firm value Fajaria \& Isnalita (2018), found that leverage significantly negatively affects firm value. Regarding the ability of earnings management to moderate, there are also differences in results where Aryantika \& Sujana (2018), find earnings management can moderate variables while research by Bukit et al. (2018), concludes earnings management is not able to moderate the effect.

\section{Research Methods}

The type of data used in this research is secondary data. We sourced from annual financial reports and share prices of manufacturing sector companies listed on the Indonesia Stock Exchange (IDX). Twenty-four companies were sampled during the 2015-2020 research period. In this study, the independent variables are cash holding, financial ratio as measured by debt to equity ratio (DER), and profitability as measured by return on assets (ROA). The dependent variable used in this study is firm value as measured by PBV. The moderating variable in this study is earnings management as measured by the non-discretionary accruals (NDA) variable.

This study uses moderated regression analysis (MRA) as the research analysis instrument. Data analysis was also used for hypothesis testing with an F test (combined effect) and t-test (partial). MRA is used by comparing the ordinary regression equation with a regression that includes independent interaction variables and moderating variables (Ghozali, 2018). The regression equation made in this research is:

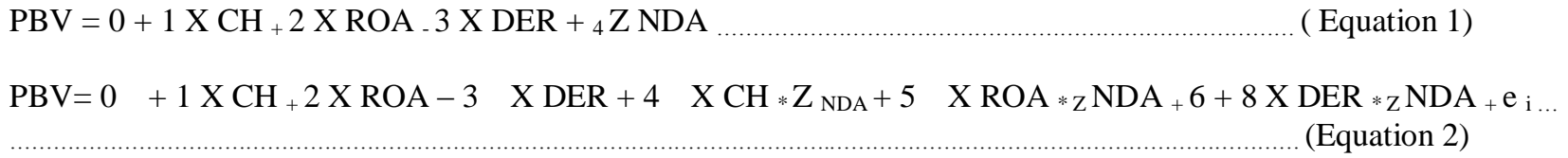
(Equation 2)

\section{Results and Discussion}

\section{Descriptive analysis results}

Descriptive statistics itself aims to illustrate each research variable (Ferdinand, 2014). Descriptive statistics provide an overview of each trait in the studied variables, which are presented in information on the minimum, maximum, mean, and standard deviation values. Each type of a variable determines the nature of the calculated descriptive statistics and how one reports or displays those statistics (Larson, 2006). 
Table 1

Descriptive statistics

\begin{tabular}{|c|c|c|c|c|c|}
\hline Variable & $\mathrm{N}$ & Minimum & Maximum & Mean & Std. Deviation \\
\hline Cash Holding(x) & & 0.0009 & 0.45130 & 0.1087 & 0.10548 \\
\hline ROA $(\%)$ & & 0.03 & 46.30 & 80.8134 & 7.57873 \\
\hline $\operatorname{DER}(\mathrm{x})$ & 144 & 0.0035 & 3,1600 & 0.7077 & 0.5247950 \\
\hline NDA & & -0.2496 & 0.11797892 & -0.05322 & 0.0575704 \\
\hline $\operatorname{PBV}(x)$ & & 0.12 & 82.44 & 4.36 & 11.52454 \\
\hline
\end{tabular}

Source: SPSS output data processing

The table above presents a description of each variable with its respective values. It can be seen from the table that all variables except NDA and PBV have good data distribution based on the average value, which is greater than the standard deviation. The data is transformed using the natural $\log (\mathrm{Ln})$ for each variable, and the NDA variable is added with numbers to avoid missing the data. The transformation aims to cure the problem of classical assumptions on the data.

\section{F-Test (F Test)}

The $\mathrm{F}$ test aims to see whether the model can be used and is feasible to test the effect of the independent variable on the dependent variable. Decision-making on the value of Prob. F, which can be seen from the statistical output. Suppose the calculated F value is more significant than the F table and the Prob. F value is less than 0.05 , and it can be concluded that all independent variables have an effect together.

Table 2

F Test Results

\begin{tabular}{ll}
\hline Mark & Coefficient \\
\hline Account & 31,103 \\
Fable & 2.44 \\
Sig & 0.000 \\
\hline \multicolumn{2}{l}{ Source: SPSS output data processing }
\end{tabular}

The table above shows the Fount value of 31.103, which is greater than the Fable value, which is only 2.44 Sig value smaller than the 0.05 significance level, indicating that together the independent variables in this study affect firm value $(\mathrm{PBV})$.

\section{Individual Parameter Significance Test (t-Test)}

The t-test is used to partially test the effect of the independent variable on the dependent variable.

Table 3

Significance test results

\begin{tabular}{|c|c|c|c|c|c|}
\hline \multirow[t]{2}{*}{ Model } & \multicolumn{2}{|c|}{$\begin{array}{l}\text { Unstandardized } \\
\text { Coefficients }\end{array}$} & \multirow{2}{*}{$\begin{array}{c}\text { Standardized } \\
\text { Coefficients }\end{array}$} & \multirow[t]{2}{*}{$\mathrm{t}$} & \multirow[t]{2}{*}{ Sig. } \\
\hline & $\mathrm{B}$ & Std. Error & & & \\
\hline (Constant) & -0.448 & 0.278 & & $-1,615$ & 0.109 \\
\hline LnCash_Holding & -0.075 & 0.062 & -0.085 & $-1,209$ & 0.229 \\
\hline LnROA & 0.569 & 0.064 & 0.627 & 8,912 & 0.000 \\
\hline LnDER & 0.325 & 0.087 & 0.243 & 3,743 & 0.000 \\
\hline Linda & -0.005 & 1.145 & 0.000 & -0.004 & 0.997 \\
\hline
\end{tabular}

Source: SPSS output data processing 
Based on the table above, the regression equation can also be made as follows:

$$
\text { LnPBV }=-0.448-0.075_{\text {LnCash_Holding }}+0.569_{\text {LnROA }}+0.325 \text { LnDER }-0.005_{\text {LnNDA }}
$$

Based on the results of data processing in table 3 the above equation can be described as follows:

- The value -0.448 is a constant value that shows the PBV value if all variables are 0 .

- The cash holding variable based on the table above counts -1.209 where the value is smaller than the t-table of 1.977, Value of Sig. is also shown to be greater than the specified significance level of $0.229>0.05$. Based on these two things, it can be concluded that cash holding does not affect PBV or firm value, so the proposed hypothesis 1 is not accepted. The coefficient or sensitivity value can be seen from the beta column, which is 0.075 . The coefficient value indicates that if the cash holding value increases or decreases by one unit or $1 \%$, it will increase or decrease the PBV in the opposite direction by -0.075 or -0.075 .

- The profitability variable as measured by ROA shows the count value is more significant than the t-table, namely 8.912>1.977. The Sig value shown is smaller than the specified significance level of $0.05 \%, 0.0000$. Based on these two statements, it can be concluded that ROA significantly affects PBV. The direction of influence can be seen from the coefficient value of the ROa variable, which shows a positive value of 0.569 . An increase in ROA of one unit or $1 \%$ will increase PBV by $0.569 \%$. Hypothesis 2 is accepted because profitability, as measured by ROA, has a positive and significant effect on PBV.

- The following variable is financial leverage as measured by DER in this study. The value of count is known to be greater than the t-table, namely 3.743>1.977, and the value of Sig is smaller than 0.05 , indicating that DER has a significant effect on firm value. The direction shown is positively indicated by the coefficient value of 0.325 . Hypothesis 3 is rejected because DER does not have a negative but positive effect on firm value.

- The earnings management variable measured by NDA shows a Sig value more significant than the significance level, namely $0.997>0.05$. This result does not follow the proposed hypothesis 4 , where good earnings management will increase or positively affect firm value.

\section{Moderated Regression Analysis (MRA)}

Regression included interaction variables between moderator variables and independent variables, and the results are as follows:

Table 4

Moderation test results

\begin{tabular}{|c|c|c|c|c|c|}
\hline \multirow[t]{2}{*}{ Model } & \multicolumn{2}{|c|}{$\begin{array}{c}\text { Unstandardized } \\
\text { Coefficients }\end{array}$} & \multirow{2}{*}{$\begin{array}{c}\begin{array}{c}\text { Standardized } \\
\text { Coefficients }\end{array} \\
\text { Beta } \\
\end{array}$} & \multirow[t]{2}{*}{$\mathrm{t}$} & \multirow[t]{2}{*}{ Sig. } \\
\hline & B & Std. Error & & & \\
\hline (Constant) & -0202 & 0.446 & & -0.453 & 0.651 \\
\hline LnCash_Holding & -0.044 & 0.085 & -0.050 & -0.521 & 0.603 \\
\hline LnROA & 0.480 & 0.125 & 0.529 & 3,843 & 0.000 \\
\hline LnDER & 0.282 & 0.152 & 0.212 & 1,856 & 0.066 \\
\hline LnNDA & 2,923 & 4.154 & 0.163 & 0.704 & 0.483 \\
\hline LnCashHolding*LnNDA & 0.423 & 0.700 & 0.100 & 0.605 & 0.546 \\
\hline LnROA*LnNDA & -1.065 & 1,274 & -0.144 & -0.836 & 0.405 \\
\hline LnDER*LnNDA & -0.731 & 1,731 & -0.057 & -0.422 & 0.673 \\
\hline
\end{tabular}

Source: processed data (SPSS output)

Based on table 4 above, the CashHolding*NDA interaction variable shows the value of Sig. above the 0.05 level value is $0.546>0.05$. The interaction variable of ROA*NDA also shows a Sig value greater than 0.05 and $90.405>$ 0.05 ). The results show that the interaction variable DER*NDA has a Sig value of 0.673 , greater than 0.05 . These results indicate that earnings management cannot act as a moderating variable.

Based on the previous output results, table 4 shows that cash holding does not have a significant effect on firm value (PBV). These results are not in line with the signaling theory underlying this study. Signal theory illustrates 
that anything good from the company will signal external parties where the company continues to strive to provide the signal. Cash holding has two sides, good and bad when viewed from the side of investors (Kim et al., 2011; Venkiteshwaran, 2011). A lot of cash value will give a slight sense of security because if the company has a problem, the company can use the most liquid assets to solve the problem. On the wrong side, if too much cash accumulates, it shows that its management is not good because the cash does not rotate. Too much cash value also shows the company is passive or inactive to use its money to increase its operations. The results of this study are in line with the research of (Do et al., 2016).

As measured by ROA, table 4 shows that profitability has a significant positive effect on firm value (PBV). This result is in line with the signal theory proposed, where ROA is one of the signals given by the company to external parties such as investors. A high ROA value reflects a high rate of return or return. The increase in ROA indicates an increase in net income obtained from the assets used and indicates the company's level of efficiency using its assets. A high rate of return will attract investors to name their capital because a high ROA shows its level of competence in managing its assets. These results are also in line with previous studies, such as research by Jihadi et al. (2021), Ratulangi (2021), Butar-Butar et al. (2021), Mubyarto (2020), Antoro et al. (2020), Tumanggor (2019), Aryantika \& Sujana (2018), Burhanuddin et al. (2019), Dewi \& Suputra (2019), Bukit et al. (2018), Agrippina et al. (2017), Sucuahi \& Cambarihan (2016).

The study results indicate that DER has a significant positive effect on firm value (PBV). Although the results are significant, the direction shown is contrary to the proposed hypothesis, so they are rejected because they do not match the hypothesis. These results indicate that the higher the DER, the higher the firm value. The DER variable itself shows the level of debt to equity where the higher the DER, the more outstanding the debt compared to the equity. The high debt will make the company hold more risk because of the interest on the debt that must be paid. Debt itself can be profitable for the company if it is appropriately managed and optimally where debt will benefit a certain level. The results of this study are in line with the results of Jihadi et al. (2021), Burhanuddin et al. (2019), Agrippina et al. (2017), Adenugba et al. (2016).

Based on the results of the previous output, namely in table 4, it can be concluded that earnings management has no significant effect on firm value (PBV). This result is not following the proposed hypothesis 4 , where good earnings management should increase firm value. Excellent and efficient earnings management will attract investors because of its ability to manage its profits. This result also contradicts the signaling theory, where a well-managed profit will be a good signal for investors.

Based on the moderating test used, it was found that earnings management cannot act as a moderating variable for the effect of cash holding, profitability (ROA), financial leverage (DER) (Goel et al., 2015; Jermias, 2008). These results are based on the interaction variables of earnings management, and the independent variables show Sig values which are all greater than 0.05 . These results do not follow hypotheses 5,6 , and 7 that are proposed to reject these hypotheses. The results show that earnings management is not proven to strengthen the independent and dependent variables' influence (Amelia et al., 2021).

\section{Conclusion}

This study concludes that cash holding earnings management has no significant effect on the value of the manufacturing company (PBV) listed on the Indonesia Stock Exchange during the 2015-2020 period. Profitability (ROA) and financial leverage (DER) have a significant positive effect on firm value (PBV). Earnings management does not have a moderating role in the effect of cash holding, profitability (ROA), financial leverage (DER) on company value (PBV) of manufactures listed on the Indonesia Stock Exchange during the 2015-2020 period.

\section{Acknowledgments}

This research can be carried out well thanks to the help of various parties. The researcher would like to thank PT. Semen Baturaja (Persero) Tbk and the Master of Management Study Program, Faculty of Economics, Sriwijaya University, as well as the parties who provided good cooperation in this research.

\section{References}

Adenugba, A. A., Ige, A. A., \& Kesinro, O. R. (2016). Financial leverage and firms' value: A study of selected firms in Nigeria. European Journal of Research and Reflection in Management Sciences, 4(1).

Agrippina, I., Fachrudin., Khaira Amalia Fachrudin., Siburian, R. (2017). The Influence of Capital Structure, Growth Opportunity and Profitability at Mining Companies in Indonesia. Res. J. Finance Account. 8.

Alsyouf, I. (2007). The role of maintenance in improving companies' productivity and profitability. International Journal of production economics, 105(1), 70-78. https://doi.org/10.1016/j.ijpe.2004.06.057 
Amelia, D. F., Adam, M., Isnurhadi, I., \& Widiyanti, M. (2021). Market performance and corporate governance in banking sector Indonesia stock exchange. International Journal of Business, Economics \& Management, 4(1), 17. https://doi.org/10.31295/ijbem.v4n1.400

Anton, R., Adam, M., Isnurhadi, I., \& Widiyanti, M. (2020). Financial, operational, and sustainability capabilities on the progress of mining companies in the Indonesia stock exchange. International Journal of Business, Economics \& Management, 3(1), 157-164. https://doi.org/10.31295/ijbem.v3n1.164

Antoro, W., Sanusi, A., \& Asih, P. (2020). The Effect of Profitability, Company Size, Company Growth on Firm Value Through Capital Structure in Food and Beverage Companies on the Indonesia Stock Exchange 2014-2018 Period. International Journal of Advances in Scientific Research and Engineering, 6(09), 36-43.

Aryantika, N. P. P., \& Sujana, I. K. (2018). Earnings Management and Managerial Ownership Moderate the Influence of Profitability on Firm Value.

Bukit, R. B., Nasution, F. N., Ginting, P., Sambath, P., \& Nurzaimah, M. (2018, January). The Influence of Firm Performance, Firm Size and Debt Monitoring on Firm Value: The Moderating Role of Earnings Management. In 1st Economics and Business International Conference 2017 (EBIC 2017) (pp. 583-588). Atlantis Press.

Burhanuddin., Marlina Widiyanti., Taufik. (2019). The Role of Profitability as an Intervening Variable on Analysis Impact of Debt Policy, Company Growth on Firm Value of Property and Real Estate Listed in Indonesia Stock Exchange. Int. J. Sci. Res. Eng. Dev. 2, 312-322.

Butar-Butar, T.T.R., Khaira Amalia Fachrudin., \& Syahputra, S.A. (2021). Analysis of the Effect of Profitability and Leverage on Firm Value with Dividend Policy as an Intervening Variable in Business Index Companies27, 20162019 Period. Int. J. Res. Rev. 8.

Cashman, G. D., Gillan, S. L., \& Jun, C. (2012). Going overboard? On busy directors and firm value. Journal of Banking \& Finance, 36(12), 3248-3259. https://doi.org/10.1016/j.jbankfin.2012.07.003

Do, T. T. N., \& Pham, H. A. (2016). Cash holding, state ownership and firm value: The case of Vietnam. International Journal of Economics and Financial Issues.

Doan, T. (2020). The effect of cash holdings on firm performance: Evidence from Vietnam listed firms. Accounting, 6(5), 721-726.

Fajaria, A. Z., \& Isnalita, N. I. D. N. (2018). The effect of profitability, liquidity, leverage and firm growth of firm value with its dividend policy as a moderating variable. International Journal of Managerial Studies and Research (IJMSR), 6(10), 55-69.

Ferdinand, A. (2014). Metode Penelitian Manajemen: Pedoman Penelitian untuk Penulisan Skripsi Tesis dan Desrtasi Ilmu Manajemen.

Ghozali, I. (2018). Aplikasi analisis multivariate dengan program IBM SPSS 25.

Goel, U., Chadha, S., \& Sharma, A. K. (2015). Operating liquidity and financial leverage: Evidences from Indian machinery industry. Procedia-Social and Behavioral Sciences, 189, 344-350. https://doi.org/10.1016/j.sbspro.2015.03.230

HC, R. H. K., Hanafi, M. M., \& Lantara, W. N. (2019). The Effect of Optimal Cash and Deviation from Target Cash on the Firm Value: Empirical Study in Indonesian Firms. JDM (Jurnal Dinamika Manajemen), 10(1), 1-13.

Jermias, J. (2008). The relative influence of competitive intensity and business strategy on the relationship between financial leverage and performance. The British Accounting Review, 40(1), 71-86. https://doi.org/10.1016/j.bar.2007.11.001

Jihadi, M., Vilantika, E., Hashemi, S. M., Arifin, Z., Bachtiar, Y., \& Sholichah, F. (2021). The effect of liquidity, leverage, and profitability on firm value: Empirical evidence from Indonesia. The Journal of Asian Finance, Economics and Business, 8(3), 423-431.

Kim, J., Kim, H., \& Woods, D. (2011). Determinants of corporate cash-holding levels: An empirical examination of the restaurant industry. International Journal of Hospitality Management, 30(3), 568-574. https://doi.org/10.1016/j.ijhm.2010.10.004

La Rocca, M., \& Cambrea, D. R. (2019). The effect of cash holdings on firm performance in large Italian companies. Journal of International Financial Management \& Accounting, 30(1), 30-59.

Lamtiar, S., Arnas, Y., Rusdiyanto, A. A., Kalbuana, N., Prasetyo, B., Kurnianto, B., ... \& Utami, S. (2021). Liquidity Effect, Profitability Leverage to Company Value: A Case Study Indonesia. European Journal of Molecular \& Clinical Medicine, 7(11), 2800-2822.

Larson, M. G. (2006). Descriptive statistics and graphical displays. Circulation, 114(1), 76-81.

Lo, K. (2008). Earnings management and earnings quality. Journal of accounting and economics, 45(2-3), 350-357. https://doi.org/10.1016/j.jacceco.2007.08.002 
McNichols, M. F. (2000). Research design issues in earnings management studies. Journal of accounting and public policy, 19(4-5), 313-345. https://doi.org/10.1016/S0278-4254(00)00018-1

Mubyarto, N. (2020). The Influence of Profitability on Firm Value using Capital Structure As The Mediator. Jurnal Economia, 16(2), 184-199.

Pasiouras, F., \& Kosmidou, K. (2007). Factors influencing the profitability of domestic and foreign commercial banks in the European Union. Research in International Business and Finance, 21(2), 222-237. https://doi.org/10.1016/j.ribaf.2006.03.007

Ratulangi, R.L.S. (2021). The Effect Of Profitability, Firm Size, Equity Ownership And Firm Age On Firm Value (Leverage Basis): Evidence from the Indonesian Manufacturer Companies. Arch. Bus. Res. 9, 128-139.

Shalahuddin, M., Adam, M., \& Widiyanti, M. (2020). The Influence of Intellectual Capital on Firm Value with Financial Performance as Intervening Variable in Banking Companies Listed in Indonesia Stock Exchange. Int. J. Bussiness Manag. Econmic Rev. IJBMER 3, 126-137.

Sucuahi, W., \& Cambarihan, J. M. (2016). Influence of profitability to the firm value of diversified companies in the Philippines. Accounting and Finance Research, 5(2), 149-153.

Sulastri, Y., Hanafi, A., \& Dewi, A. (2018). The effect of stock ownership structure, capital structure, and profitability to firm value in manufacturing company sector in Indonesia stock exchange. International Journal of Scientific and Technology Research, 7(11), 187-192.

Suputra, I. D. D. (2019). Pengaruh Profitabilitas dan Leverage pada Nilai Perusahaan dengan Corporate Social Responsibility Sebagai Variabel Pemoderasi Ni Made Laksmi Dewi. E-Jurnal Akuntansi, 28, 26-54.

Tumanggor, A. H. (2019). The Effect Of Capital Structure, Firm Growth, Firm Size And Profitability On Firm Value Of Companies With Good Corporate Governance As A Moderating Variables In Manufacturing Companies In The Basic And Chemical Industry Registered In Indonesia Stock Exchange. International Journal of Public Budgeting, Accounting and Finance, 2(3), 1-13.

Tumanggor, A.H., Erlina, Bukit, R., 2019. The Effect of Capital Structure, Firm Growth, Firm size and Profitability on Firm Value of Companies with Good Corporate Governance as a Moderating Variables in Manfacturing Companies in the Basic and Chemical Industry Registered in Indonesia Stock Exchan. Int. J. Public Budg. Account. Finance 2, 1-13.

Venkiteshwaran, V. (2011). Partial adjustment toward optimal cash holding levels. Review of Financial Economics, 20(3), 113-121. https://doi.org/10.1016/j.rfe.2011.06.002

Villalonga, B., \& Amit, R. (2006). How do family ownership, control and management affect firm value?. Journal of financial Economics, 80(2), 385-417. https://doi.org/10.1016/j.jfineco.2004.12.005 